\title{
Erratum to: Solitude, Religious and Cultural Uniqueness in a Foreign Environment: Adjustments as an Arab Student
}

\author{
Hamzeh Y. Abunab ${ }^{1}$ (D) Wireen Leila T. Dator ${ }^{2} \cdot$ \\ Jordan T. Salvador ${ }^{3} \cdot$ Mary Grace C. Lacanaria $^{1}$
}

Published online: 29 June 2017

(C) Springer Science+Business Media, LLC 2017

\section{Erratum to: J Relig Health DOI 10.1007/s10943-017-0425-x}

In the original publication, the article title was inadvertently published with an error. The explanatory note included along with the article title has been deleted. The correct title should be: Solitude, Religious and Cultural Uniqueness in a Foreign Environment: Adjustments as an Arab Student.

The original article was corrected.

The online version of the original article can be found under doi:10.1007/s10943-017-0425-x.

\section{Hamzeh Y. Abunab}

Habunab2015@gmail.com

1 Saint Louis University, Baguio City, Philippines

2 Princess Nourah Bint Abdulrahman University, Riyadh, Saudi Arabia

3 University of Dammam, Dammam, Saudi Arabia 